УДК: 61:004.45

Семенець Андрій Володимирович

кандидат технічних наук, доцент кафедри медичної інформатики

Тернопільський державний медичний університет ім. І. Я. Горбачевського, м. Тернопіль, Україна

semteacher@mail.ru

\title{
ПРОБЛЕМА ПІДТРИМКИ ВЕРСІЙ СИСТЕМИ ДИСТАНЦІЙНОЇ ОСВІТИ MOODLE В МЕДИЧНОМУ ВНЗ
}

\begin{abstract}
Анотація. Система дистанційної освіти Moodle - один із лідерів серед вільнорозповсюджуваного програмного забезпечення, що використовується для підтримки навчального процесу. У роботі вивчено проблему оновлення застарілої версії системи дистанційної освіти Moodle. Показано приклад успішної реалізації процедури оновлення на прикладі Тернопільського державного медичного університету ім. І. Я. Горбачевського. Описано основі етапи процесу оновлення й перенесення СДО Moodle на новий сервер. Наведено приклади застосування технології віртуалізації і системи контролю версій у задачах системного адміністрування СДО Moodle. Представлено рекомендації зі здійснення оптимізації програмного оточення СДО Moodle.
\end{abstract}

Ключові слова: програмне забезпечення 3 відкритим кодом; оновлення програмного забезпечення; система дистанційної освіти; система контролю версій; віртуалізація; резервне копіювання.

\section{1. ВСТУП}

Постановка проблеми. Інформатизація системи охорони здоров'я належить до числа ключових загальнодержавних завдань. Від успішного й ефективного їх розв'язання залежить перспектива України в досяжному майбутньому зайняти достойне місце серед розвинутих країн 3 високим рівнем соціального захисту населення. Наразі галузь медичної освіти має забезпечити підготовку фахівців, здатних ефективно використовувати можливості сучасних медичних інформаційних систем, i брати участь у їх розробці і супроводженні [1].

Застосування вільно-розповсюджуваного програмного забезпечення (ПЗ) 3 відкритим кодом - важливий елемент сучасного підходу до реалізації навчального процесу в медичній освіті. Підтримка вільно-розповсюджуваного ПЗ в актуальному стані - обов'язкова умова забезпечення його ефективного, надійного та безпечного використання.

Аналіз останніх досліджень i публікацій. Інформатизація медичної освіти грунтується, у першу чергу, на впровадженні ПЗ інформаційних систем (IC) керування навчанням (СКН чи LMS - Learning Management System), які часто ще називають системами дистанційної освіти (СДО), та систем керування навчальними матеріалами (CКНM або LCMS — Learning Content Management System).

У роботі [2] було детально розглянуто концептуальні підходи до автоматизації освітніх процесів у медичному навчальному закладі. Вказано як переваги, так i недоліки застосування з цією метою вільно-розповсюджуваного ПЗ СКН/СДО/СКНМ 3 відкритим кодом.

За останні роки в галузі медичної освіти України суттєво активізувалася діяльність з упровадження IC СКН/СДО/СКНМ $[3,4,5]$. Безперечними лідерами серед ПЗ СКН/СДО/СКНМ з відкритим кодом є СДО Moodle (http://moodle.org/) й aTutor (http://atutor.ca/), що мають величезний набір функцій і широко застосовуються в навчальних закладах багатьох країн світу. Зокрема, на сайті спільноти Moodle лише 
офіційно зареєстровано понад 300 українських навчальних закладів, що використовують СДО Moodle [6], а реально їх набагато більше.

Упровадження СДО Moodle в навчальний процес Тернопільського державного медичного університету ім. І. Я. Горбачевського розпочалося у 2006 році з версії Moodle 1.6. Використовувалося СДО Moodle, в основному, для здійснення тестового контролю під час самопідготовки студентів до занять у рамках кредитно-модульної системи організації навчального процесу (КМСОНП) [7, 8].

Мета статті. Як було вказано вище, однією з обов'язкових умов ефективного використання вільно-розповсюджуваного ПЗ СКН/СДО/СКНМ є підтримка його в актуальному стані шляхом своєчасного встановлення необхідних оновлень. Проте статистичні дані свідчать про поширену практику застосування застарілих версій різноманітного ПЗ. Не виключенням є і напрям інформатизації освітніх процесів. За даними [9] половину з майже 65000 зареєстрованих копій СДО Moodle становлять застарілі версії (1.9.х). Ця обставина свідчить про високу актуальність розробки методик проведення оновлення й модернізації ПЗ СДО Moodle 3 метою приведення його до актуального стану. У процесі оновлення ПЗ адміністратор СДО Moodle стикається 3 комплексом різноманітних проблем, спричинених конкретними особливостями наявних апаратно-програмних засобів.

Метою роботи є презентація досвіду успішного здійснення оновлення застарілої версії СДО Moodle в Тернопільському державному медичному університеті ім. І. Я. Горбачевського. Процес оновлення ПЗ ускладнювався наявністю незадокументованих модифікацій програмного коду. Представлено загальні рекомендації і приклад детальної покрокової інструкції з оновлення СДО Moodle для вказаних умов.

\section{2. МЕТОДИ ДОСЛІДЖЕННЯ}

\section{1. Підстави і планування оновлення СДО Moodle в ТДМУ}

Восени 2012 року комп’ютерна мережа ТДМУ стала ціллю серйозної хакерської атаки. Під час ліквідації наслідків атаки було розроблено план реорганізації інформаційної системи ТДМУ. Один $з$ кроків передбачав оновлення СДО Мoodle, оскільки наявна версія 1.9.1+ (збірка 20080618) вже не підтримувалася розробниками й містила відомі суттєві вразливості. Попри це, у 2010 році на тому самому апаратному сервері було паралельно встановлено окрему копію (уже версії 2.1) СДО Moodle для потреб HНI медсестринства і центру дистанційного навчання університету. Ця обставина додатково ускладнила процеси адміністрування серверу.

Враховуючи суттєвий обсяг даних у СДО Moodle ТДМУ [2], автор запропонував поданий нижче порядок оновлення СДО Moodle.

1. Створення копії головного серверу на основі повної резервної копії.

2. Інвентаризація змін програмного коду і системних налаштувань серверу СДО Moodle.

3. Перенесення СДО Moodle ННІ медсестринства на окремий виділений сервер.

4. Розробка детальної покрокової інструкції процесу оновлення головного серверу.

5. Застосування розробленої інструкції для оновлення головного серверу СДО Moodle.

6. Оновлення СДО Moodle HНІ медсестринства до версії, що використовується на головному сервері СДО Moodle. 
Інша мета роботи - стандартизувати програмне середовище обох копій СДО Moodle для полегшення його адміністрування і супроводження в майбутньому.

\section{2. Підготовчий етап - резервне копіювання й інвентаризація налаштувань серверу}

Резервне копіювання. Повну резервну копію вдалося створити лише 3 використанням LiveCD на основі OC Linux - за допомогою програми $\boldsymbol{d} \boldsymbol{d}$. Інші засоби резервування, такі як Acronis Rescue Media 2012 і Paragon Hard Disk Manager Suite 2011, наявні в автора, не змогли без помилок скопіювати жорсткий диск з партиціями, що відформатовані у файлову систему ехt4.

Інвентаризація програмного коду СДО Moodle. Кількісний склад модулів залишався стандартним, однак програмісти ТДМУ внесли низку значних модифікацій до програмного коду деяких із них. Слід відзначити негативний факт документування змін практично не велося. Це призвело до того, що оновлювати програмний код СДО Moodle стало неможливо. Повну інвентаризацію змін програмного коду СДО Moodle вдалося здійснити лише за допомогою системи контролю версій (CКВ) git (http://git-scm.com/), розмістивши код на особистому ПК автора. Вказана процедура детально описана в роботі [10].

Інвентаризація налаштувань серверу. Інвентаризація системних налаштувань (i спілкування 3 попереднім адміністратором) показала наявність такої конфігурації серверу СДО Moodle ТДМУ (перелічено лише окремі найсуттєвіші параметри конфігурації ПЗ):

- OC: Debian 6;

- веб-сервер: nginx версії 0.9.6. Виконує сайти:

- /var/www/nursery/htdocs - сайт СДО Moodle HНІ медсестринства ТДМУ, версія 2.1.1 (збірка 20110801);

- /var/www/moodle/moodle - основний сайт СДО Moodle ТДМУ, версія 1.9.1+ (збірка 20080618);

- дві версії процесора скриптів РНР:

- 5.2.1 - модифікована вручну попереднім адміністратором серверу шляхом компіляції з вихідних кодів, застосовується 3 основним сайтом СДО Moodle ТДМУ;

- 5.3.3 - працює в режимі FastCGI, встановлена 3 репозиторію, застосовується із сайтом СДО Moodle HНІ медсестринства;

- СУРБД MySql версії 5.1.55. Наявні дві БД:

- dl (формат InnoDB) - застосовується із сайтом СДО Moodle HНI медсестринства ТДМУ;

- moodle (формат MyISAM) - застосовується 3 основним сайтом СДО Moodle ТДМУ.

\section{3. РЕЗУЛЬТАТИ ДОСЛІДЖЕННЯ. РЕАЛІЗАЦІЯ ПРОЦЕДУРИ ОНОВЛЕННЯ СДО МООDLЕ}

\section{1. Перша спроба - оновлення серверу СДО Moodle в цілому}

На першому етапі автором було зроблено спробу оновлення існуючого серверу в цілому. Для цього новостворену резервну копію було розгорнуто на окремому фізичному комп’ютері-сервері. Запуск копії сервера пройшов штатно. 
Тестова спроба здійснити оновлення основного сайту СДО Moodle відповідно до рекомендацій $[11,12,13]$ уже на першому кроці показала необхідність додавання низки php-бібліотек, зокрема iconv, curl, $\boldsymbol{x m l r p c}$ та dom. Оновлення РНР шляхом компіляції $з$ вихідних кодів $є$ складною процедурою [14]. Враховуючи це, й усвідомлюючи таку саму складність кожної наступної спроби оновлення в майбутньому, особливо під час переходу на новіші версії процесора скриптів РНР, автором було прийнято рішення про недоцільність оновлення існуючого серверу СДО Moodle в цілому.

\section{2. Перенесення СДО Moodle на новий сервер}

\subsection{1. Крок 1 - оновлення СДО Mооdle до версії 1.9.19}

Враховуючи вищесказане, автором було розпочато процедуру перенесення СДО Moodle на новий фізичний сервер. Тимчасово було використано ПК на базі процесора AMD Opteron 4122 (4 ядерний) з ОЗП 8 Гб (DDR3) та двома накопичувачами ємністю по 500 Гб. Операційна система - Ubuntu Server 12.04 LTS. Дані зі старого сервера мали такий обсяг:

- резервна копія програмного коду СДО Moodle - 90 Мб;

- д дані курсів (папка moodledata) - 21 Гб (в архіві - 5,5 Гб);

- дамп бази даних (БД) - 10 ГБ (в архіві - 1,5 Гб).

Згідно рекомендацій $[7,9]$ спершу було виконано оновлення СДО Moodle до версії 1.9.19. Вказана операція пройшла штатно і без помилок. Зазвичай, модифікації, зроблені програмістами ТДМУ, були при цьому втрачені. Однак на даному етапі це визнано несуттєвим фактом, оскільки робота з інвентаризації змін програмного коду СДО Moodle велася одночасно [10].

Ідентифіковано і видалено вбудованими засобами керування 2 блоки сторонніх розробників, несумісних із новими версіями СДО Moodle: "Академічні групи" і "Choice to group". За допомогою інструменту керування СУРБД MySql - PhpMyAdmin очищено таблицю mdl_question_states. Обсяг БД зменшився до 8,8 Гб.

На цьому перший етап перенесення було завершено. Дану резервну копію серверу СДО Moodle пізніше було розгорнуто в мережевому кластері ТДМУ 3 використанням окремого доменного імені. Вказаний сервер працює в режимі "лише для читання", що усуває необхідність у спеціально модифікованому програмному коді. Такі кроки були спричинені поданими далі вимогами.

1. Необхідністю зберегти попередні оцінки студентів.

2. Неможливістю їх перенесення під час оновлення СДО Moodle до версії > 2.0 згідно даних $[11,13,15]$.

Ще одна тестова спроба оновлення СДО Moodle до версії 2.2 згідно [12] на даному етапі також завершилася невдало 3 численними помилками БД. Сервер повторно відновлено до вказаного вище стану з використанням резервної копії.

\subsection{2. Крок 2 - очистка блоків і видів активності}

Було визначено, що основну цінність в існуючій БД СДО Moodle становить структура курсів і банк тестових завдань. Вирішено всі зусилля спрямувати на їх збереження під час оновлення. Тому наступним етапом було очищення СДО Moodle від неактуальних і помилкових інстанцій блоків і видів діяльності.

1. Видалено імплементації з курсів такого переліку блоків (Керування - Modules - Blocks - Manage blocks) - Course/site Description, Global search, Loan calculator, Mentees, Messages, Quiz results, HTML blocks, Random glossary entry, Remore RSS, Tags, Section Links, Social tasks - сумарно близько 60 шт. 
2. Видалено імплементації 3 курсів наступного переліку видів діяльності (Керування - Modules - Ресурси курсу - Manage activities) - База даних, Урок, Чam - сумарно близько 20 шт.

3. Видалено самі види діяльності (Керування - Modules - Ресурси курсу — Manage activities) і їх файли із сервера (згідно рекомендацій [9]): Hot Potatoes Quiz, LAMS, Workshop, Journal. Додатково видалено види діяльності, що додавалися автором [4]: Checklist i Scheduler.

Вказані операції дозволили також незначно зменшити обсяг БД. Цей крок також завершено створенням резервної копії БД та файлів.

\subsection{3. Крок 4 - перетворення БД у формат InпоDВ}

Bepciï СДО Moodle > 2.0 працюють виключно з форматом баз даних InnoDB. Відносно великий обсяг БД СДО Moodle ТДМУ і наявні в ній помилки структур даних призвели до того, що спроби застосувати наведені в [16] методи автоматичного конвертування вбудованими засобами СДО Moodle завершувалися невдало. Авторові довелося здійснювати конвертування в ручному режимі.

1. Проведено максимально можливу очистку БД з метою зменшення іï обсягу й усунення можливих помилок у структурах даних. Очищено вміст таких таблиць: mdl_log, mdl_backup_log, mdl_question_states, mdl_question_session, mdl_question_attempts, mdl_event_all, mdl_message, mdl_message_read, mdl_user_last_access, mdl_cache_text, mdl_cache_blogs, mdl_cache_filters, mdl_grade_grades, mdl_grade_grades_history, $\quad m d l \_g r a d e \_i t e m s \_h i s t o r y$, mdl_grade_categories_history, mdl_quiz_grades, mdl_quiz_attempts, mdl_quiz_feedback. $\mathrm{Y}$ результаті розмір БД було зменшено до 3,3 Гб. 3 них 2,5 Гб склав обсяг таблиць, що містять тестові завдання.

2. Визначено таблиці й поля в них, що мають невідповідне кодування за допомогою SQL-запитів:

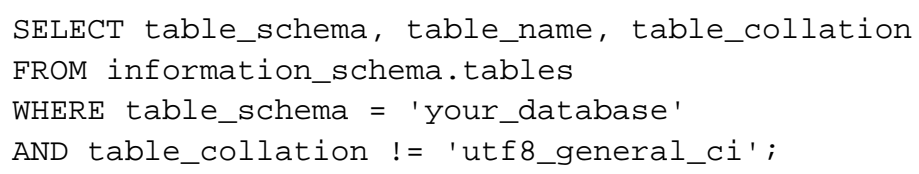

i, відповідно для полів таблиць:

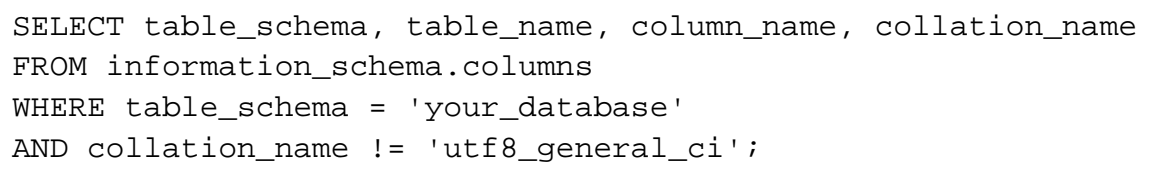

Знайдені об'єкти БД приведено до стандартного, у сучасних версіях СДО Moodle, кодування utf8_general_ci за допомогою SQL-запиту:

ALTER TABLE 'tablename' CONVERT TO CHARACTER SET utf8 COLLATE

utf8_general_ci;

3. Конвертування таблиць БД у формат здійснювалося за допомогою такого SQLзапиту

ALTER TABLE table_name ENGINE=InnoDB; 
Як аргумент вказувався відразу список з багатьох таблиць. Виключення склали таблиці mdl_question, mdl_question_answers та mdl_question_multichoice - через великий розмір, кожна з них оброблялася окремо.

4. Виправлено останніх кілька помилок у БД, що були виявлені раніше, зокрема, у таблиці mdl_resource для поля reference повторно встановлено тип даних varchar(255), а в таблиці mdl_context видалено рядок 3 дублікатом значення "10" для поля contextlevel. Останній параметр критичний для оновлення, так само, як і роль таблиці mdl_context для функціонування СДО Moodle в цілому. Слід бути обережними під час внесення змін до цієї таблиці.

5. За результатами роботи зроблено чергову резервну копію БД.

\subsection{4. Четвертий крок - оновлення до актуальної версії}

Після вищевказаних робіт, чергова спроба здійснити оновлення до версії 2.2.5 відповідно до вказівок [12] завершилася успішно. Оновлення здійснювалося 3 використанням термінального інтерфейсу і відповідних засобів адміністрування [17]. Цей варіант має кілька переваг — він зручний під час використання системи контролю версій і оновлення сайтів з БД великого обсягу. Слід зазначити, що процес оновлення до версії 2.2.5 тривав близько 2 годин часу за $100 \%$ завантаження тестового сервера.

За результатами вищеперелічених кроків (пп. 3.2.1-3.2.4) автором складено покрокову і деталізовану інструкцію процесу оновлення. Ця інструкція була надалі практично застосована в оновленні головного серверу СДО Moodle ТДМУ.

\subsection{5. Віртуалізація, оновлення, налаштування та оптимізація головного серверу СДО Moodle ТДМУ}

Віртуалізація. Після завершення осіннього семестру 2012-2013 н. р., розроблену вище інструкцію було застосовано до оновлення головного серверу СДО Moodle ТДМУ. Для цього в мережевому кластері ТДМУ [2] створено новий віртуальний сервер. Основні параметри апаратного забезпечення:

- фізична нода - 2* Intel Xeon E5-2609 (2,4 ГГц, 4 ядра), 64 Гб ОЗП, 4 накопичувачі: $2 * 500 Г б$ (10000 об/хв) RAID0 + 2*2Тб (7200 об/хв). Середовище віртуалізації - Proxmox VE;

- віртуальний сервер - 1 процесор (фізичний), 32 Гб ОЗП, обсяг накопичувача - 400 Гб. Операційна система — Ubuntu Server 12.04 LTS.

Оновлення. На цьому віртуальному сервері розгорнуто актуальну резервну копію СДО Moodle, яка була згідно розробленої інструкції послідовно оновлена:

- до версії 1.9.19;

- до версії 2.2.7 - максимально можливої під час оновлення з 1.9.х ;

- до версії 2.4.1, актуальної на момент здійснення оновлення (лютий 2013 р.).

Слід відзначити, що надалі процес оновлення СДО Moodle вже не викликав таких серйозних проблем, зокрема, протягом 2013 року оновлення здійснювалося ще тричі:

- червень 2013 - оновлення до версії 2.4.4+ ;

- вересень 2013 - оновлення до версії 2.5.2 ;

- січень 2014 - оновлення до версії 2.6.1 .

У подальшому автором заплановано здійснювати оновлення двічі на рік — під час зимових і літніх канікул, щоб не спричиняти незручностей здійснення навчального процесу у ВНЗ.

Налаштування. Після завершення процедури оновлення, здійснено процес базового налаштування СДО Moodle відповідно до вимог ТДМУ.

1. Застосовано версію скриптів програмного коду СДО Moodle з модифікаціями для ТДМУ. Для цього використано функціональні можливості створеного, за 
результатами роботи [10], спеціально для потреб ТДМУ, репозиторію на сервері GitHub (https://github.com/semteacher/moodle/).

2. Встановлено модулі діяльності "Контрольний список" i "Розклад" 3 модифікаціями для ТДМУ $[18,19]$ з відповідних репозиторіїв автора на сервері GitHub (https://github.com/semteacher/moodle-checklist i https://github.com/semteacher/moodle-mod_scheduler).

3. Встановлено необхідні адміністративні параметри. Зокрема, задано час зберігання логів (максимум 6 місяців) — для запобігання надмірного зростання БД. Також, налаштовано виконання скрипту автоматизації операцій Cron згідно [20], що є необхідною умовою для надсилання email повідомлень, збору статистичних даних, виконання адміністративних задач за розкладом.

4. Запроваджено використання домашньої сторінки користувача, яка містить перелік і надає швидкий доступ до курсів, у яких бере участь користувач.

5. Здійснено численні дрібні налаштування, що стосуються деталей відображення блоків на сторінках сайту СДО Moodle.

Оптимізація. Упродовж перших днів експлуатації оновленого СДО Moodle ТДМУ було виявлено серйозні проблеми з продуктивністю сервера. У першу чергу використання великої кількості ОЗП і надмірне навантаження на процесори сервера. На рис. 1 показано навантаження на сервер за одночасної роботи більше 400 користувачів.

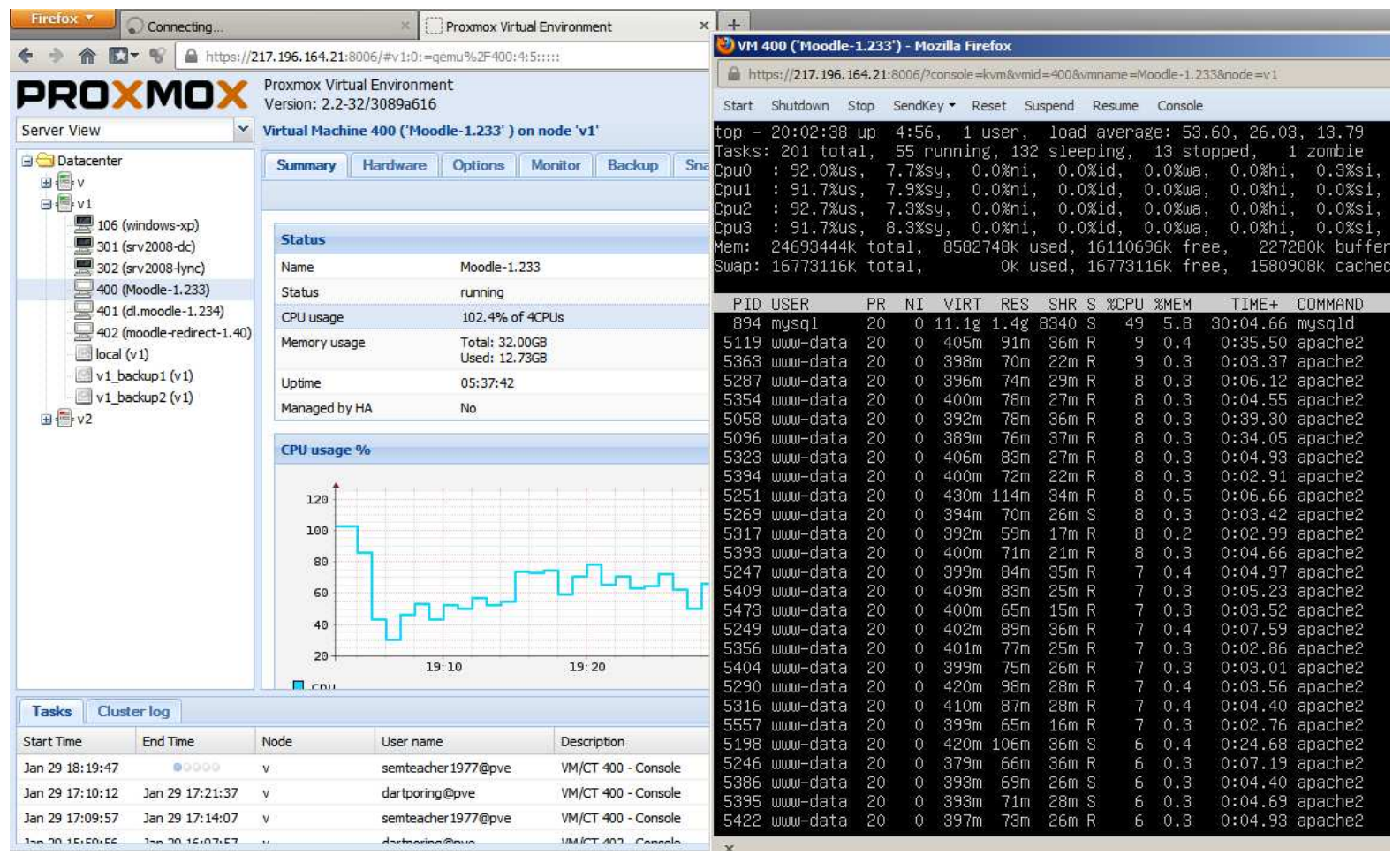

Рис. 1. Навантаження оновленого серверу СДО Моodle ТДМУ до здійснення оптимізачії налаштувань (> 400 користувачів одночасно)

Ключові параметри оптимізації налаштувань самого СДО Moodle розглянуто детально в документації $[21,22]$. Необхідно також здійснити низку налаштувань, як описано в $[23,24]$, програмного оточення самого сервера, на якому працює СДО Moodle. 
Процес оптимізації зайняв доволі тривалий період часу. У результаті вдалося добитися параметрів навантаження на сервер, близьких до описаних в [22] (див. рис. 2). На рис. 3 показано типову активність користувачів СДО Moodle ТДМУ на прикладі інтервалу в 2 тижні.

Для збереження конфігураційних файлів серверу створено спеціальний репозиторій СКВ на сервері GitHub (https://github.com/semteacher/moodle_settings), у який поміщено подане далі.

1. Конфігураційні файли веб-сервера Apache i окремих його додатків процесора скриптів РНР і модуля кешування даних АРС.

2. Конфігураційний файл СУРБД MySql.

3. Конфігураційний файл мережевих налаштувань.

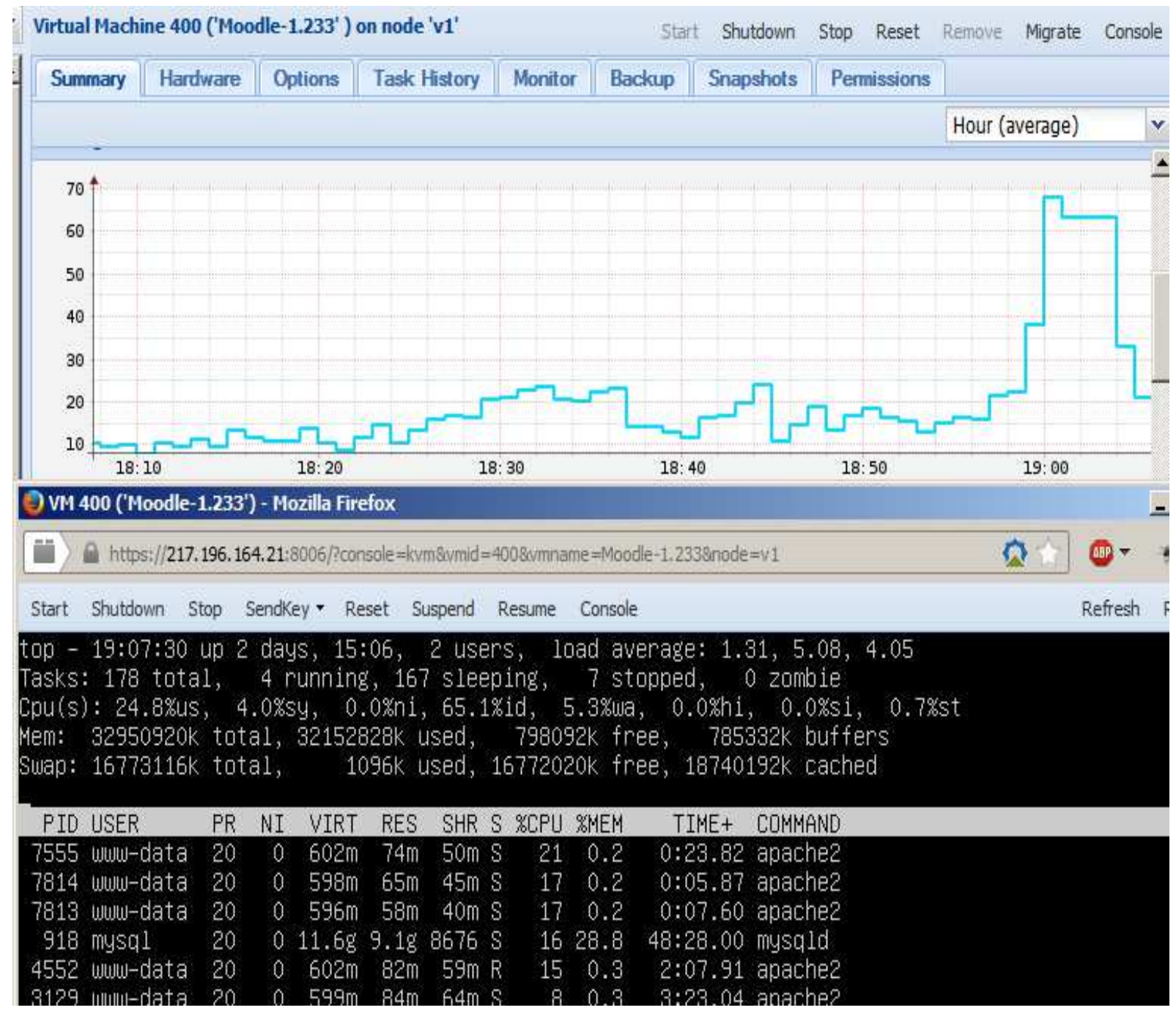

Рис. 2. Навантаження оновленого серверу СДО Моодle ТДМУ після здійснення оптимізачії налаштувань (> 450 користувачів одночасно) 


\section{ТДМУ - Вся діяльність (всі ролі)}

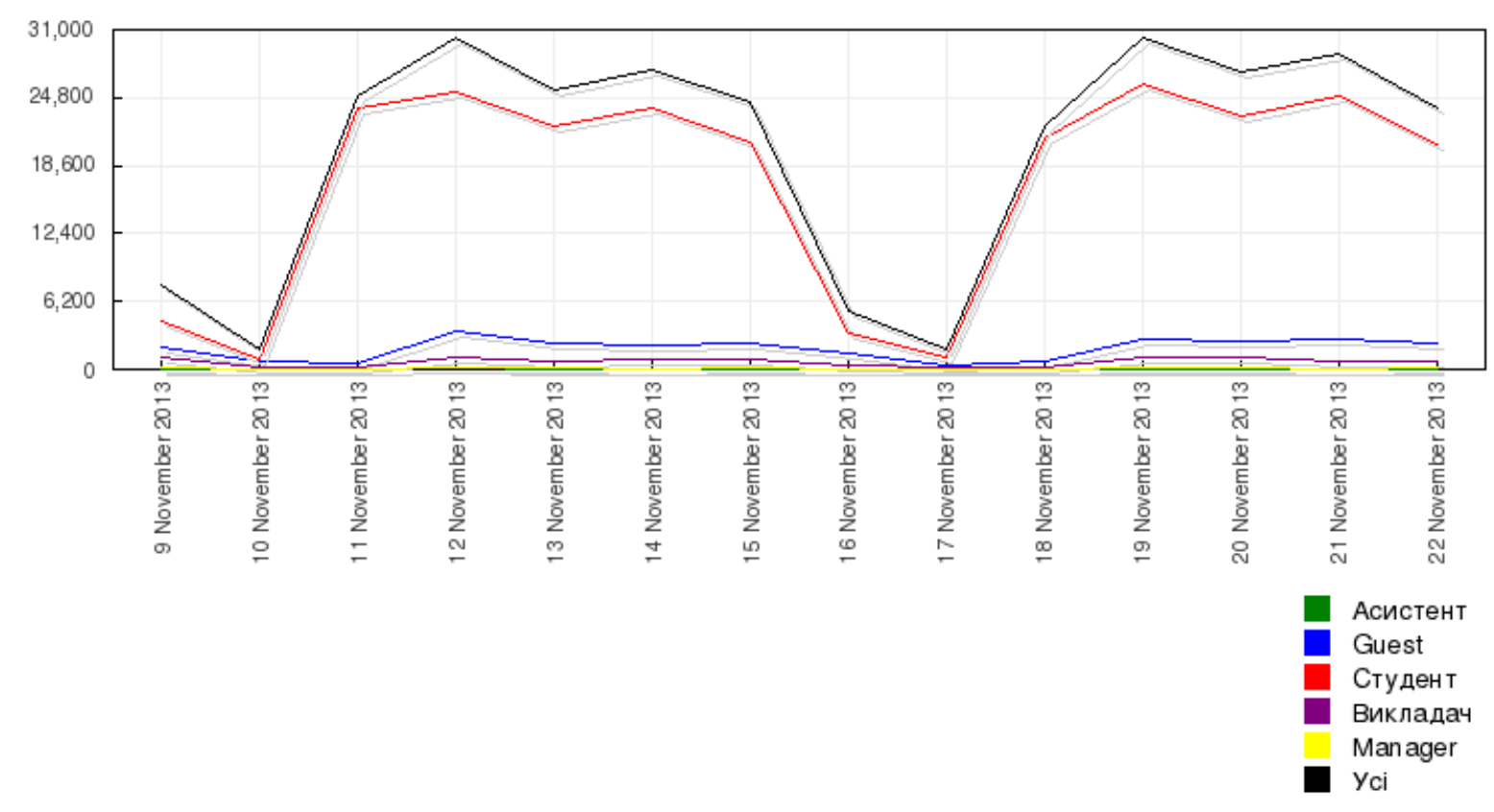

Рис. 3. Середня активність користувачів СДО Моодlе ТДМУ (період спостереження - 2 тижні)

\section{4. ВИСНОВКИ ТА ПЕРСПЕКТИВИ ПОДАЛЬШИХ ДОСЛІДЖЕНЬ}

Застосування вільно-розповсюджуваного ПЗ з відкритим кодом - важливий елемент сучасного підходу до реалізації навчального процесу в медичній освіті. СДО Moodle - один із лідерів серед вільно-розповсюджуваного ПЗ СКН/СДО/СКНМ 3 відкритим кодом. Підтримка ПЗ, що використовується в освітньому процесі в актуальному стані - обов'язкова умова забезпечення його ефективного й безпечного використання.

1. У роботі показано досвід успішного здійснення оновлення СДО Moodle від застарілої версії 1.9 до актуальної 2.6.1, у Тернопільському державному медичному університеті ім. І. Я. Горбачевського. Представлено загальні рекомендації і приклад детальної покрокової інструкції з оновлення СДО Moodle для вказаних умов. Актуальність інструкції підтверджується статистичними даними про використання аналогічних застарілих версій СДО Moodle великою кількістю навчальних закладів.

2. Наведено додаткові рекомендації загального плану, що сприяють успішному проведенню оновлення застарілих версій вільно-розповсюджуваного ПЗ 3 відкритим кодом (на прикладі СДО Moodle), зокрема:

- наявність резервної копії (чи кількох одночасно) програмного середовища;

- наявність тестового апаратно-програмного середовища для безпечного проведення експериментів;

- застосування системи контролю версій для модифікації програмного коду (за можливості — також і налаштувань ПЗ);

- необхідність документування змін як в програмному коді, так i параметрів налаштування ПЗ. 
3. Продемонстровано переваги використання засобів віртуалізації апаратних засобів серверів у процесі розгортання, оновлення та експлуатації СДО Moodle в умовах медичного ВН3.

\section{СПИСОК ВИКОРИСТАНИХ ДЖЕРЕЛ}

1. Качмар В. О. Медичні інформаційні системи - стан розвитку в Україні. / В. О. Качмар // Український журнал телемедицини та медичної телематики. — 2010. — Том 8. — № 1. - С. 6773.

2. Семенець А. В. Впровадження інформаційно-комунікаційних технологій - необхідна умова ефективної розробки та супроводження сучасних програмних продуктів. / А. В. Семенець // Кредитно-модульна система організації навчального процесу у вищих медичних (фармацевтичних) навчальних закладах України на новому етапі : матеріали X ювілейної Всеукр. навч.-наук. конф. 3 міжнар. участю (Тернопіль, 18-19 квіт. 2013 р.) : у 2 ч. / Терноп. держ. мед. унт ім. І. Я. Горбачевського. - Тернопіль : ТДМУ, 2013. - Ч. 1. — С. 455-463.

3. Фетісов В. С. Комп'ютерні технології в тестуванні / В. С. Фетісов [Електронний ресурс]. -2011. - Режим доступу до документу : http://moodle.ndu.edu.ua/file.php/1/Fetisov_komp_tehnol_v-testuvanni.pdf.

4. Центри ДО в Україні // Освітній портал / [Електронний ресурс]. - Режим доступу до документу : http://www.osvita.org.ua/distance/ukraine/centers/.

5. Дистанційна Освіта в Україні [Електронний ресурс]. - Режим доступу до документу: http://lib.if.ua/publish2008/1217424966.html.

6. Moodle.org: Registered sites [Електронний pecypc]. - Режим доступу до документу : https://moodle.org/sites/index.php?country=UA.

7. Ковальчук Л. Я. Комп'ютерні технології в медичній освіті / Л. Я. Ковальчук, В. П. Марценюк // Медична інформатика та інженерія. — 2008. — № 1. - С. 14-16.

8. Ковальчук Л. Я. Впровадження новітніх методик і систем навчального процесу в Тернопільському державному медичному університеті імені I. Я. Горбачевського / Л. Я. Ковальчук // Медична освіта. — 2009. - № 2. - С. 10-14.

9. Moodle Statistics [Електронний pecypc]. — Режим доступу до документу : https://moodle.org/stats/.

10. Семенець А. В. Адаптація вільно-розповсюджуваного ПЗ з відкритим кодом для підтримки навчального процесу в окремому медичному ВН3 / А. В. Семенець // Медична інформатика та інженерія. — 2013. - № 4. - С. 57-66.

11. Upgrading to Moodle 2.3 [Електронний pecypc]. - Режим доступу до документу: http://docs.moodle.org/23/en/Upgrading_to_Moodle_2.3.

12. Upgrading to Moodle 2.2 [Електронний pecypc]. - Режим доступу до документу: http://docs.moodle.org/22/en/Upgrading_to_Moodle_2.2.

13. Upgrading to Moodle 2.0 [Електронний pecypc]. - Режим доступу до документу : http://docs.moodle.org/20/en/Upgrading_to_Moodle_2.0.

14. Compiling PHP from source [Електронний pecypc]. — Режим доступу до документу: http://docs.moodle.org/22/en/Compiling_PHP_from_source.

15. Upgrade Moodle 1.9.17 to 2.2.3 SUCCESS! [Електронний ресурс]. — Режим доступу до документу : https://moodle. org/mod/forum/discuss.php?d=205367.

16. Migration from MyISAM to InnoDB [Електронний pecypc]. - Режим доступу до документу: http://docs.moodle.org/21/en/Migration_from_MyISAM_to_InnoDB.

17. Administration via command line [Електронний pecypc]. - Режим доступу до документу: http://docs.moodle.org/22/en/Administration_via_command_line.

18. Марценюк В. П. Модуль реєстрації виконання студентами матрикулів практичних навичок та оцінок за ОСКІ в системі електронного контролю знань на базі СДО Moodle / В. П. Марценюк, А. В. Семенець // Запорожский медицинский журнал. — 2013. - № 1. - С. 123.

19. Семенець А. В. Модуль формування розкладу відробок практичних занять та самозапису студентів в системі електронного контролю знань на базі СДО Moodle / А. В. Семенець, В. П. Марценюк // Матеріали Всеукраїнської науково-методичної відеоконференції 3 міжнародною участю "Актуальні питання дистанційної освіти та телемедицини - 2013" (Запоріжжя, Київ, Лондон, 1011 жовтня 2013 р.) // Запорожский медицинский журнал. — 2013. — № 6. - С. 119-120.

20. Cron [Електронний pecypc]. - Режим доступу до документу : http://docs.moodle.org/all/hr/Cron. 
21. Caching [Електронний pecypc]. - Режим доступу до документу: http://docs.moodle.org/26/en/Caching.

22. Performance settings [Електронний pecypc]. - Режим доступу до документу : http://docs.moodle.org/26/en/Performance_settings.

23. Nevers F. Moodle performance testing: how much more horsepower do each new versions of Moodle require? / F. Nevers [Електронний pecypc]. — Режим доступу до документу: http://www.iteachwithmoodle.com/2012/10/12/moodle-performance-testing-how-much-morehorsepower-do-each-new-versions-of-moodle-require/.

24. Performance recommendations [Електронний pecypc]. - Режим доступу до документу: http://docs.moodle.org/26/en/Performance_recommendations.

Матеріал надійшов до редакиіï 29.12.2013 p.

\title{
ПРОБЛЕМА ПОДДЕРЖКИ ВЕРСИЙ СИСТЕМЫ ДИСТАНЦИОННОГО ОБРАЗОВАНИЯ МООDLЕ В МЕДИЦИНСКОМ ВУЗе
}

\section{Семенец Андрей Владимирович}

кандидат технических наук, доцент кафедры медицинской информатики

Тернопольский государственный медицинский университет им. И. Я. Горбачевского, г. Тернополь, Украина

semteacher@mail.ru

\begin{abstract}
Аннотация. Система дистанционного образования Moodle - один из лидеров среди свободно-распространяемого программного обеспечения, используемого для поддержки учебного процесса. В работе изучена проблема обновления устаревшей версии системы дистанционного образования Moodle. Показан пример успешной реализации процедуры обновления модифицированной версии на примере Тернопольского государственного медицинского университета им. И. Я. Горбачевского. Описаны основные этапы процесса обновления и переноса СДО Moodle на новый сервер. Приведены примеры применения технологии виртуализации и системы контроля версий в задачах системного администрирования СДО Moodle. Представлены рекомендации по осуществлению оптимизации программного окружения СДО Moodle.
\end{abstract}

Ключевые слова: программное обеспечение с открытым кодом; обновление программного обеспечения; система дистанционного образования; система контроля версий; виртуализция; резервное копирование.

\section{PROBLEM OF SUPPORTING THE VERSIONS OF DISTANCE EDUCATION SYSTEM MOODLE IN THE MEDICAL UNIVERSITY}

\author{
Andrii V. Semenets \\ $\mathrm{PhD}$ (technical sciences), Department of Medical Informatics \\ I. Ya. Horbachevsky Ternopil State Medical University, Ternopil, Ukraine \\ semteacher@mail.ru
}

\begin{abstract}
Moodle is one of the open-source software learning management system using to support an educational process. The problem of updating the outdated Moodle versions is studied in the article. It is shown a successful implementation of a modified version on the basis of I. Ya. Horbachevsky Ternopil State Medical University. The step-by-step manual of the updating and a new server migration process are described. Examples of the application of the virtualization techniques and version control system to the SDE Moodle system administration tasks solving are presented. The SDE Moodle server optimization and customization recommendations are also given.
\end{abstract}

Keywords: open-source software; learning management system; software update; version control system; virtualization; backup. 


\section{REFERENCES (TRANSLATED AND TRANSLITERATED)}

1. Kachmar V. O. Medical information systems - state of development in Ukraine. / V. O. Kachmar // Ukrainian Journal of Telemedicine and Medical Telematics. — 2010. — Volume 8. — № 1. — P. 67-73. (in Ukrainian)

2. Semenets A. V. The introduction of information and communication technologies - a necessary condition for efficient development and maintenance of modern software. / A. V. Semenets // ECTS system of educational process in higher medical (pharmaceutical) educational institutions of Ukraine in the new phase materials tenth anniversary Vseukr. Teach Science. conf. with Intern. participation (Ternopil, 18-19 Apr. 2013): 2 hours / Ternopil. State. Med. Univ im.I.Ya.Horbachevskoho. — Ternopol : Ternopil State Medical University, 2013. — Part 1. - P. 455-463. (in Ukrainian)

3. Fetisov V. S. Computer technologies in testing. [online] / V. S. Fetisov. — 2011. — Available from: http://moodle.ndu.edu.ua/file.php/1/Fetisov_komp_tehnol_v-testuvanni.pdf (in Ukrainian)

4. Distance Education Centers in Ukraine [online] // Education Portal. - Available from : http://www.osvita.org.ua/distance/ukraine/centers/ (in Ukrainian)

5. Distance Education in Ukraine [online]. - Available from : http://lib.if.ua/publish2008/1217424966.html (in Ukrainian)

6. Moodle.org: Registered sites [online]. — Available from : https://moodle.org/sites/index.php?country=UA (in English)

7. Kovalchuk L. Ya. Computer technologies in medical education / L. Ya. Kovalchuk, V. P. Martsenyuk // Medical Informatics and Engineering. - 2008. - № 1. - P. 14-16.

8. Kovalchuk L. Ya. Introduction of new methods and systems of the educational process in the Ternopil State Medical University named I. Ya. Horbachevsky / L. Ya. Kovalchuk // Medical Education. — 2009. — № 2. - P. 10-14.

9. Moodle Statistics [online]. — Available from : https://moodle.org/stats/ (in English)

10. Semenets A. V. Adapting freely distributed, open source software to support the learning process in a separate medical college. / A. V. Semenets // Medical Informatics and Engineering. — 2013. — № 4. P. 57-66. (in Ukrainian)

11. Upgrading to Moodle 2.3 [online]. — Available from : http://docs.moodle.org/23/en/Upgrading_to_Moodle_2.3 (in English)

12. Upgrading to Moodle 2.2 [online]. - Available from : http://docs.moodle.org/22/en/Upgrading_to_Moodle_2.2 (in English)

13. Upgrading to Moodle 2.0 [online]. - Available from : http://docs.moodle.org/20/en/Upgrading_to_Moodle_2.0 (in English)

14. Compiling PHP from source [online] . - Available from : http://docs.moodle.org/22/en/Compiling_PHP_from_source (in English)

15. Upgrade Moodle 1.9.17 to 2.2.3 SUCCESS! [online]. — Available from : https://moodle.org/mod/forum/discuss.php?d=205367 (in English)

16. Migration from MyISAM to InnoDB [online]. — Available from : http://docs.moodle.org/21/en/Migration_from_MyISAM_to_InnoDB (in English)

17. Administration via command line [online]. - Available from : http://docs.moodle.org/22/en/Administration_via_command_line (in English)

18. Marceniyuk V. P. Module registration matrykuliv students perform practical skills and assessment for OSKI in the electronic control knowledge-based LMS Moodle. / V. P. Marceniyuk, A. V. Semenets // Zaporozhye Medical Journal. — 2013. — № 1. — P. 123. (in Ukrainian)

19. Semenets A. V. Module formation vidrobok schedule workshops and samozapysu students in the electronic control knowledge-based LMS Moodle / A. V. Semenets, V. P. Martsenyuk // Proceedings of the All-Ukrainian scientific-methodical video conference with international participation "Current issues of distance education and telemedicine - 2013" (Kyiv, London 10-11 October 2013) // Zaporozhye medical journal. — 2013. — № 6. - P. 119-120. (in Ukrainian)

20. Cron [online]. - Available from : http://docs.moodle.org/all/hr/Cron (in English)

21. Caching [online]. - Available from : http://docs.moodle.org/26/en/Caching (in English)

22. Performance settings [online]. — Available from : http://docs.moodle.org/26/en/Performance_settings (in English)

23. Nevers F. Moodle performance testing: how much more horsepower do each new versions of Moodle require? [online] / F. Nevers. — Available from : http://www.iteachwithmoodle.com/2012/10/12/moodleperformance-testing-how-much-more-horsepower-do-each-new-versions-of-moodle-require/ (in English).

24. Performance recommendations [online]. - Available from : http://docs.moodle.org/26/en/Performance_recommendations (in English). 